\title{
1 Analysis of migration of pathogenic drug-resistant 2 bacteria to soils and groundwater after fertilization with 3 sewage sludge
}

4

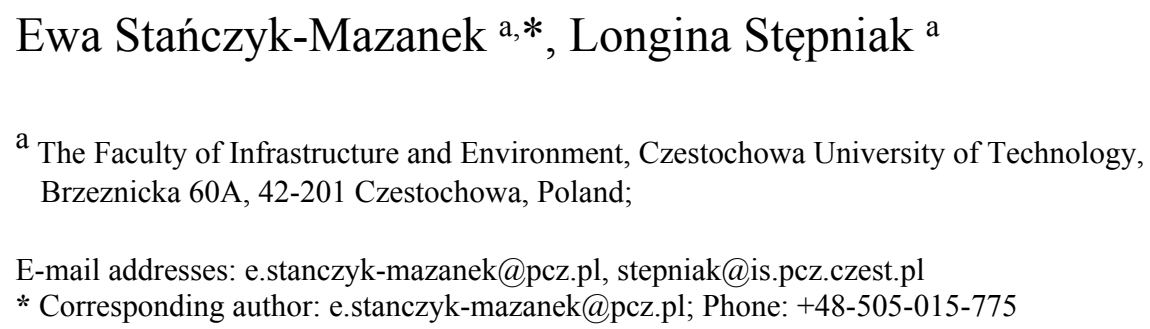

Abstract: The paper discusses the analysis of the effect of using sewage sludge for fertilization on the level of soil and groundwater contamination with drug-resistant bacteria. Other sanitary contaminants in these environments were also analysed. Composted sewage sludge was introduced into the sandy soil over a period of 6 months. The examinations were conducted under conditions of a lysimetric experiment with the possibility of collecting soil leachates (in natural conditions). The following doses of sewage sludge were used: $0,10,20,30$ and $40 \mathrm{t} /$ ha calculated per experimental object containing $10 \mathrm{~kg}$ of sandy soil. The research were carried out within the time frame of one year. Dactylis glomerata grass was grown on the fertilized soils. In soils and leachates from soils (which may have polluted groundwater) collected from fertilized experimental objects, the sanitary condition and quantity of drug-resistant bacteria (mainly from the families Enterobacteriaceae and Enterococcus) were analysed one year after fertilization. Their drug resistance to selected antibiotics was also analysed based on current recommendations.

Keywords: environmental assessment, soil, groundwater, drug-resistant bacteria, fertilization, sewage sludge

\section{Introduction}

The content of various drugs, including antibiotics, is often determined in the soil and aquatic environments. They are detected in surface water, groundwater and even in water purified and intended for consumption [1]. At the same time, new drug-resistant bacteria are often identified. They can also be found more and more often in food $[2,3]$. The sources of 
32 these pollutants are mainly wastewater from pharmaceutical industrial plants and hospitals

33 [4]. Hospital sewage is particularly dangerous [5, 6]. The sources of contamination also

34 include domestic sewage, sewage sludge and waste from agriculture and animal husbandry

35 [7- 11].

36 In wastewater treatment plants, antibiotics are removed to an insufficient level $[12,13]$. The

37 consequence is the migration of antibiotics and their toxic metabolites to the aquatic and soil

38 environment. Wastewater can be a source of contamination of soil, plants and water,

39 including rivers and seas [14], with bacteria resistant to many drugs. Studies have

40 documented the contamination of fish and shrimps with drug-resistant bacteria from the

$41 \quad$ Enterobacteriaceae family [15].

42 Fertilization of soils with organic fertilizers and waste, including sewage sludge, may cause

43 the spread of pathogenic microorganisms in the environment. There are reports on the 44 presence of drug-resistant bacteria in sludge in the literature concerning sludge management $45[12,16]$. In both sludge and a conventional organic fertilizer provided by manure, numerous 46 pathogenic forms have been found while they acquired or developed resistance mechanisms with respect to a number of antibiotics available in health care $[17,18,19]$. Particularly risky is the possible migration of these harmful forms with precipitation and water infiltrated to groundwater and further to drinking water intakes.

Sanitary cleanness of water, including groundwater, is one of the most important

51 components of contemporary water management. However, many potentially hazardous 52 microorganisms are often found in water [20].

53 The presence of sanitary indicators, intestinal bacteria and enterococci was determined in 54 the analyzed samples of sewage sludge used for fertilization, fertilized soils and waters 55 infiltrating the soils. The authors analyzed the effect of using sewage sludge for fertilization 56 (in doses $0,10,20,30$ and $40 \mathrm{t} / \mathrm{ha}$ ) on the degree of soil and groundwater contamination with drug-resistant bacteria. 
2. Materials and Methods

The examinations of the migration of drug-resistant microorganisms from sewage

71 sludge to fertilized soil and then to leachate from the soil were conducted as part of a 72 lysimetric experiment under condition of cultivation in a foil tunnel for one year.

Light soil with granulometric composition of loamy soil was used in the experiment.

The $\mathrm{pH}$ value in the soil used in the lysimetric experiment was 6.4 and, according to the fertilization recommendations [21], it exhibited poorly acid reaction. Concentration of heavy metals in the soils determined according to the standards [21] and presented in Table 1 was below permissible levels recommended for fertilization with sewage sludge $[22]$.

79 For fertilization purposes in the lysimetric experiment, the authors used the sewage sludge

80 from two wastewater treatment plants situated in the south of Poland. Sewage sludge was

81 formed after biological treatment of sewage using the activated sludge method. Then it was stabilized aerobically. After this process, sewage sludge was thickened mechanically and dewatered by means of a belt press. After dewatering of sewage sludge on belt presses, it was composted naturally in prisms (without lime additives) on plots on the site of the treatment plant for a period of 6 months.

86 The experiment was conducted in polyethylene lysimeters with capacity of $10 \mathrm{~kg}$ 87 dedicated to sludge sampling. The lysimeters were filled with sandy soil and fertilised 
with different doses of sewage sludge. The objects were fertilized with the doses calculated per pot so that they corresponded to the amount of 10, 20, 30 and 40 tons of fertilizer per hectare. The control objects with non-fertilized soils were also used in the experimental procedure. The soil mixtures fertilized in this way were sown with Dactylis glomerata grass.

The humidity during the lysimetric experiment was maintained at the level of $60 \%$ of maximum water capacity by watering with well water. The soil (collected from lysimeters at the depth of $25 \mathrm{~cm}$ ) and the leachates collected from the research objects were analysed one year after fertilization with sewage sludge. All the tests were carried out with 3 repetitions. The results are represented by mean levels from these repetitions. Soil leachates can enter surface water and also cause their microbiological contamination.

Sanitary examinations were conducted based on the recommendations for the analysed environments [23]. The content of mesophilic bacteria (potentially pathogenic -

103 on a nutrient agar), Salmonella bacteria (on SS medium) and Enterobacteriaceae and

104 Enterococcus bacteria was determined in the sewage sludge used for fertilization, soil 105 fertilized with sewage sludge and water leachates. The coliform index of Escherichia coli, 106 Clostridium perfringens and Proteus vulgaris was also determined.

108 2.3. Examinations of drug resistance of bacteria occurring in sewage sludge, soil and 109 infiltrating waters

111 from soils fertilized with sewage sludge) were also subjected to microbiological analyses, 112 which were aimed to determine the quantitative and qualitative composition of 113 drug-resistant microorganisms. A series of dilutions in saline solution (with decimal 
114 progression) were prepared at the first stage. Next, $0.1 \mathrm{ml}$ of each of the above dilutions

115 was spread on ENDO, BEA and nutrient agars (with three repetitions). Incubation of 116 microorganisms was performed for 24 hours at $37^{\circ} \mathrm{C}$.

117 Identification of individual groups of isolated microorganisms used the respective 118 selective agars mediums. Agar medium (MPA) was used to determine the total count of 119 mesophilic (potentially pathogenic) microorganisms in the samples.

120 After bacteria colonies were grown, they were sieved for three times using the 121 reduction method in order to obtain pure strains. Identification of isolated intestinal 122 bacteria was based on biochemical Microgen GN-ID A + B multitests which take into 123 consideration analysis of the capability of decomposition of 24 substrates. Enterococci 124 were identified by means of Microgen Strep ID biochemical multitests. As recommended 125 by the manufacturer of the multitests, enterococci were incubated after inoculation for 24 126 hours at temperature of $37^{\circ} \mathrm{C}$. The results of determinations were analysed by means of 127 Microgen MID 60 software.

Drug resistance of intestinal bacteria and enterococci isolated from the 129 environments studies was examined using the diffusion-disc method. The Mueller-Hinton 130 agar recommended in clinical diagnostics was used. In the case of intestinal bacteria, we 131 performed the analysis of drug susceptibility to amikacin, co-amoxiclav, cefazolin, 132 ceftazidime, cefuroxime, ciprofloxacin, ampicillin and gentamicin. In the case of 133 determination of drug resistance in enterococci, tests were performed to examine 134 susceptibility to ampicillin, ciprofloxacin, penicillin, erythromycin, streptomycin, 135 vancomycin, chloramphenicol, tetracycline, linezolid and imipenem. The drugs used are 136 most commonly used to combat these groups of microorganisms [24, 25].

137 After even spreading of the suspensions of the bacteria isolated on the 138 Mueller-Hinton agar surface (on Petri dishes), the dishes soaked with the respective antibiotics with recommended concentrations were applied and the incubation was 
141 individual antibacterial compounds were read from the interpretation tables for minimal

142 inhibiting concentrations and the size of growth inhibition zones developed by the

143 European Committee on Antimicrobial Susceptibility Testing [26].

144

145

146

147

148

149

150

\section{Results}

presented in Tables 1 and 2 .

Physical, chemical and sanitary characterization of materials used in the study is Light sandy soil was used for the examinations Its reaction was 6.4 (Tab. 1) and, according to fertilizing recommendations [21], it exhibited poorly acid reaction. The content of chromium and mercury in the control soil was within the range of the permissible concentration in soil. Taking into account to the The Institute of Soil Science and Plant Cultivation (IUNG) guidelines used to assess the degree of heavy metals contamination of soils with heavy metal, the contents of standardized metals such as zinc, lead, copper, cadmium and nickel in sandy soil used for fertilization in the lysimeter experiment could be determined as a natural quantity (0 degree of soil contamination) [27]. Concentration of heavy metals in the soils was below permissible levels recommended for fertilization with sewage sludge [22].

Table 2 presents the results of sanitary examinations used for lysimeter experiments of soil and sewage sludge.

The analysis of the results of the data presented in Table 2 showed that sandy soil did not contain sanitary contaminants. According to the recommendations [23], it could be classified as clean soil. The sewage sludge used in the experiment did not contain bacteria of the Salmonella sp. genus and could be used for fertilizing purposes. 
167

168

169

170

171

172

173

174

175

176

177

178

179 presented.

Analysis of the results presented in Table 3 found that the fertilization with sewage

Table 1.

Physical and chemical properties of soil and sewage sludge used in the lysimeter experiment

\begin{tabular}{lcll}
\hline Parameter & Unit & Soil & \multicolumn{1}{c}{ Sewage sludge } \\
\hline Organic matter & [\% d. m.] & 0.8 & 47.0 \\
$\mathrm{pH}_{\mathrm{H} 20}$ & - & 6.4 & 8.2 \\
Organic carbon & [g.kg-1 d. m.] & 9.65 & 230 \\
$\mathrm{~N}$ (total) & & 0.65 & 37.12 \\
$\mathrm{P}$ (available) & & 35.12 & 611.5 \\
$\mathrm{~K}$ (available) & & 19.49 & 262.4 \\
$\mathrm{Mg}($ available $)$ & & 59.9 & 885.4 \\
Chromium $(\mathrm{Cr})$ & & 1.6 & 19 \\
Zinc $(\mathrm{Zn})$ & 3.6 & 775 \\
Lead $(\mathrm{Pb})$ & [mg.kg $\left.{ }^{-1} \mathrm{~d} . \mathrm{m}.\right]$ & 7.1 & 27 \\
Copper $(\mathrm{Cu})$ & & 1.1 & 156 \\
Cadmium $(\mathrm{Cd})$ & & 0.1 & 2.6 \\
Nickel $(\mathrm{Ni})$ & & 0.92 & 120.1 \\
Mercury $(\mathrm{Hg})$ & & 0.0018 & 0.52 \\
\hline
\end{tabular}

d. m. - dry mass

\section{Table 2.}

Results of sanitary examinations of soil and sewage sludge used for the experiments

\begin{tabular}{|c|c|c|c|c|c|c|c|}
\hline \multirow{3}{*}{$\begin{array}{l}\text { The type } \\
\text { of } \\
\text { material } \\
\text { to be } \\
\text { tested }\end{array}$} & \multicolumn{7}{|c|}{ Determination } \\
\hline & \multicolumn{3}{|c|}{ Bacteria count } & \multicolumn{4}{|c|}{ Total bacteria count $[\mathrm{CFU} / 1 \mathrm{ml}]$} \\
\hline & $\begin{array}{l}\text { Escherichia } \\
\text { coli }\end{array}$ & $\begin{array}{l}\text { Clostridium } \\
\text { perfringens }\end{array}$ & $\begin{array}{l}\text { Proteus } \\
\text { vulgaris }\end{array}$ & Mesophilic & $\begin{array}{l}\text { From the } \\
\text { family } \\
\text { Enterobacteriaceae }\end{array}$ & $\begin{array}{l}\text { From the } \\
\text { family } \\
\text { Enterococcus }\end{array}$ & $\begin{array}{l}\text { Salmonella } \\
s p .\end{array}$ \\
\hline Soil & n. d. & n. d. & $10^{-1}$ & $3.9 \cdot 10^{3}$ & n. d. & n. d. & n. d. \\
\hline Sewage & $10^{-6}$ & $10^{-5}$ & $10^{-5}$ & $20.1 \cdot 10^{9}$ & $1.2 \cdot 10^{7}$ & $6.5 \cdot 10^{1}$ & n. d. \\
\hline
\end{tabular}
sludge

n. d.- not detected, CFU - colony forming unit

Tables 3 and 4 present the results of sanitary tests of soil fertilized with sewage sludge and leachates from these soils. The results of quantitative analyses of mesophilic bacteria and Enterobacteriaceae and Enterococcus families obtained one year after fertilization are also sludge at all doses affected the sanitary condition of the fertilized sandy soil. Only 
189

190

non-fertilised control soil could be classified as sanitary clean. The amount of mesophilic bacteria determined in soils fertilized with 20,30 and 40 t/ha suggests soil contamination. The total number of bacteria of above $2.5 \cdot 10^{6}$ according to the pattern for the assessment of soil sanitary condition indicated its pollution [23]. Similarly, the determination of other sanitary indices, including Escherichia coli indicates low contamination after application of doses of 10 and 20 t/ha and strong contamination of fertilized soils after application of doses 30 and 40 t/ha. Similar observations were found for anaerobes (Clostridium perfringens). There was also an increase in the number of spoilage bacteria in the fertilized soils, which was evidenced by the Proteus vulgaris. The use of sewage sludge also caused a significant increase in the number of intestinal bacteria from the Enterobacteriaceae family.

The results presented in Table 4 prove that microorganisms from fertilizing materials, including sewage sludge, are likely to migrate to soils and further to groundwater. The increase of mesophilic (potentially pathogenic) and intestinal Enterobacteriaceae bacteria was determined in the leachates from sandy soil fertilized with sewage sludge. The lowest contamination was found after application of the dose of $10 \mathrm{t} / \mathrm{ha}$.

\section{Table 3.}

Results of sanitary examinations of soil fertilized with different doses of sewage sludge (after completion of the experiment)

\begin{tabular}{|c|c|c|c|c|c|c|}
\hline \multirow{3}{*}{$\begin{array}{l}\text { Dose of sewage } \\
\text { sludge applied for } \\
\text { soil fertilization } \\
\text { [t/ha] }\end{array}$} & \multicolumn{6}{|c|}{ Determinations in soil fertilized with sewage sludge } \\
\hline & \multicolumn{3}{|c|}{ Bacteria count } & \multicolumn{3}{|c|}{ Total bacteria count $[\mathrm{CFU} / 1 \mathrm{ml}]$} \\
\hline & $\begin{array}{l}\text { Escherichia } \\
\text { coli }\end{array}$ & $\begin{array}{l}\text { Clostridium } \\
\text { perfringens }\end{array}$ & $\begin{array}{l}\text { Proteus } \\
\text { vulgaris }\end{array}$ & Mesophilic & $\begin{array}{l}\text { From the family } \\
\text { Enterobacteriaceae }\end{array}$ & $\begin{array}{l}\text { From } \\
\text { the family } \\
\text { Enterococcus }\end{array}$ \\
\hline 0 & n. d. & n. d. & $10^{-1}$ & $2.4 \cdot 10^{3}$ & n. d. & n. d. \\
\hline 10 & $10^{-1}$ & $10^{-2}$ & $10^{-3}$ & $3.5 \cdot 10^{5}$ & $5.2 \cdot 10^{4}$ & 2 \\
\hline 20 & $10^{-1}$ & $10^{-2}$ & $10^{-4}$ & $4.5 \cdot 10^{6}$ & $3.7 \cdot 10^{5}$ & 6 \\
\hline 30 & $10^{-3}$ & $10^{-3}$ & $10^{-4}$ & $6.2 \cdot 10^{6}$ & $4.3 \cdot 10^{5}$ & 9 \\
\hline
\end{tabular}


40

$10^{-4}$

$10^{-3}$

$10^{-5}$

Table 4.

211 Results of sanitary examinations of water leachates from soil fertilized with different doses

212 of sewage sludge (after completion of the experiment)

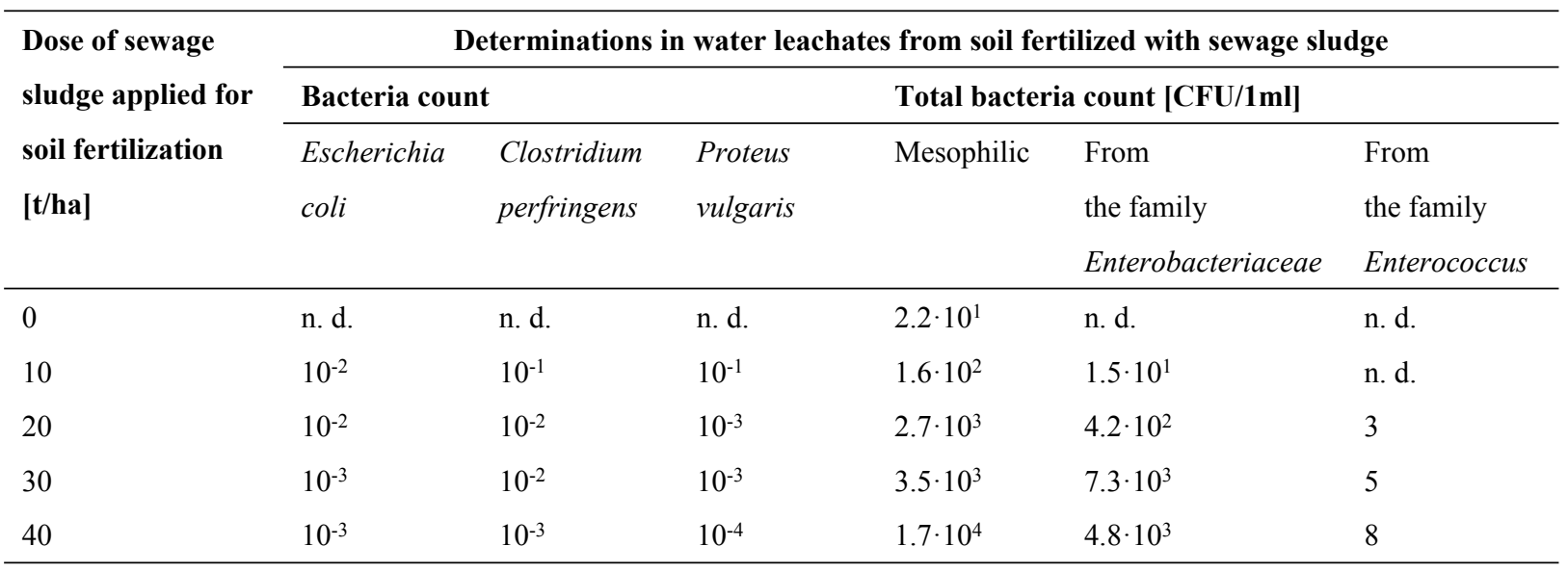

n. d. - not detected, CFU - colony forming unit

Table 5 presents the results of tests of resistance to selected antibiotics of bacterial species isolated from sewage sludge. Tables 6-8 show the results of drug resistance of bacteria isolated from soils and water leachates (from soil mixtures) fertilized with sewage sludge.

The data in Tables 2 and 5 show that Enterobacteriaceae are the most abundant

220 intestinal bacteria in sewage sludge. A smaller group of bacteria are Enterococcus family.

221 Few species were isolated from this group of organisms: E. faecalis, E. faecium and E. gallinarum (Tab. 8). All three species were found in sewage sludge and fertilized soil. The species migrating to and determined in soil was E. faecalis. An increase in the number of

224 these microorganisms in the soil with an increase in the fertilization dose was observed.

225 Sanitary parameters determined in soil leachates indicated significant exceeding of 226 parameters in relation to waters used for drinking [28] and bathing purposes. According to 227 the standards, water used e.g. for bathing purposes should not contain more than $100 \mathrm{CFU}$ 
228 per $100 \mathrm{ml}$. After application of doses of 20,30 and $40 \mathrm{t} / \mathrm{ha}$ of sewage sludge to the soil, the

229 level of water infiltrating the fertilized soil did not meet the above requirements. A worrying

230 phenomenon was the observed resistance of E. faecalis bacteria to erythromycin.

231 The examinations showed that sewage sludge is a significant source of drug-resistant

232 Enterobacteriaceae bacteria in organic soils fertilized with this waste (Tab. 5 and 6). It was

233 also shown that these microorganisms may migrate together with soil leachate to

234 groundwater, posing a real threat to the environment (Tab. 7). It was found that only a dose of

$23510 \mathrm{t} / \mathrm{ha}$ of sewage sludge did not cause significant contamination of sandy soil and infiltrating

236 water.

$237 \quad$ Table 5.

238 Results of antibiograms for individual bacteria from the Enterobacteriaceae family and

239 saprophytic bacteria isolated from sewage sludge

\begin{tabular}{|c|c|c|c|c|c|c|c|c|}
\hline \multirow{2}{*}{$\begin{array}{l}\text { Bacteria species isolated } \\
\text { from sewage sludge }\end{array}$} & \multicolumn{8}{|c|}{ Type of antibiotic used } \\
\hline & 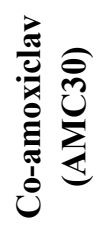 & 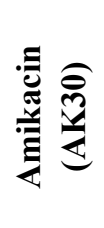 & 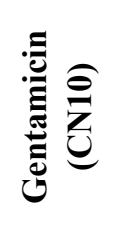 & 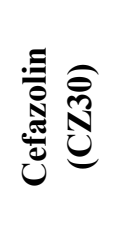 & 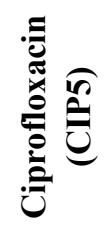 & 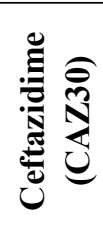 & 哥浂 & 晷 \\
\hline Citrobacter freundii & $\mathrm{S}$ & $\mathrm{S}$ & $\mathrm{S}$ & $\mathrm{S}$ & $\mathrm{S}$ & $\mathrm{S}$ & MS & $\mathrm{S}$ \\
\hline Morganella morganii & $\mathrm{R}$ & $\mathrm{S}$ & $\mathrm{S}$ & $\mathrm{R}$ & $\mathrm{S}$ & $\mathrm{S}$ & $\mathrm{R}$ & MS \\
\hline Klebsiella pneumoniae & $\mathrm{S}$ & $\mathrm{S}$ & $\mathrm{S}$ & $\mathrm{S}$ & $\mathrm{S}$ & $\mathrm{S}$ & MS & $\mathrm{S}$ \\
\hline Klebsiella oxytoca & $\mathrm{S}$ & $\mathrm{R}$ & $\mathrm{S}$ & $\mathrm{S}$ & $\mathrm{S}$ & $\mathrm{S}$ & $\mathrm{R}$ & $\mathrm{S}$ \\
\hline Yersinia aldovae & $\mathrm{S}$ & $\mathrm{S}$ & $\mathrm{S}$ & $\mathrm{S}$ & $\mathrm{S}$ & $\mathrm{S}$ & $\mathrm{R}$ & $\mathrm{S}$ \\
\hline Yersinia enterocolitica & $\mathrm{R}$ & $\mathrm{S}$ & $\mathrm{R}$ & $\mathrm{S}$ & $\mathrm{S}$ & $\mathrm{R}$ & $\mathrm{R}$ & $\mathrm{S}$ \\
\hline Serratia marcescens & $\mathrm{S}$ & $\mathrm{S}$ & $\mathrm{S}$ & $\mathrm{R}$ & $\mathrm{S}$ & $\mathrm{S}$ & $\mathrm{S}$ & $\mathrm{S}$ \\
\hline Serratia rubidaea & $\mathrm{S}$ & $\mathrm{S}$ & $\mathrm{S}$ & $\mathrm{S}$ & $\mathrm{S}$ & $\mathrm{S}$ & MS & S \\
\hline Burkholderia pseudomallei & $\mathrm{R}$ & $\mathrm{S}$ & $\mathrm{S}$ & $\mathrm{S}$ & $\mathrm{S}$ & $\mathrm{S}$ & $\mathrm{R}$ & $\mathrm{S}$ \\
\hline Pseudomonas fluorescens* & $\mathrm{R}$ & $\mathrm{S}$ & $\mathrm{S}$ & $\mathrm{S}$ & $\mathrm{S}$ & $\mathrm{S}$ & $\mathrm{S}$ & $\mathrm{S}$ \\
\hline Pseudomonas stutzeri* & $\mathrm{S}$ & $\mathrm{S}$ & $\mathrm{S}$ & $\mathrm{S}$ & $\mathrm{S}$ & $\mathrm{S}$ & $\mathrm{R}$ & $\mathrm{S}$ \\
\hline Alcaligenes faecalis* & $\mathrm{S}$ & $\mathrm{S}$ & $\mathrm{R}$ & $\mathrm{S}$ & $\mathrm{S}$ & $\mathrm{S}$ & $\mathrm{S}$ & $\mathrm{R}$ \\
\hline Photorhabdus luminescens & $\mathrm{S}$ & $\mathrm{S}$ & $\mathrm{S}$ & $\mathrm{S}$ & $\mathrm{S}$ & $\mathrm{S}$ & $\mathrm{R}$ & $\mathrm{S}$ \\
\hline Proteus vulgaris & $\mathrm{S}$ & $\mathrm{S}$ & $\mathrm{S}$ & $\mathrm{R}$ & $\mathrm{S}$ & MS & $\mathrm{R}$ & $\mathrm{R}$ \\
\hline Providencia rettgeri & $\mathrm{S}$ & $\mathrm{S}$ & $\mathrm{S}$ & $\mathrm{S}$ & $\mathrm{S}$ & $\mathrm{S}$ & $\mathrm{R}$ & $\mathrm{S}$ \\
\hline Providencia stuartii & $\mathrm{R}$ & $\mathrm{S}$ & $\mathrm{S}$ & $\mathrm{R}$ & $\mathrm{S}$ & MS & $\mathrm{R}$ & $\mathrm{R}$ \\
\hline
\end{tabular}


Enterobacter kobei

Eschericha coli

Eschericha coli

E. coli-inactive L+

E. coli-inactive L-

Enteric Group

$\begin{array}{ccc}\text { S } & \text { MS } & \text { S } \\ \text { S } & \text { S } & \text { S } \\ \text { R } & \text { S } & \text { S } \\ \text { R } & \text { S } & \text { S } \\ \text { S } & \text { S } & \text { S } \\ \text { R } & \text { S } & \text { S }\end{array}$

$\mathrm{S}$
$\mathrm{S}$
$\mathrm{S}$
$\mathrm{S}$
$\mathrm{S}$
$\mathrm{S}$

S

S

S

S

S

S

$\mathrm{S}$
$\mathrm{S}$
$\mathrm{S}$
$\mathrm{S}$
$\mathrm{S}$
$\mathrm{S}$

$\begin{array}{cc}\text { R } & \text { S } \\ \text { S } & \text { S } \\ \text { R } & \text { S } \\ \text { R } & \text { S } \\ \text { R } & \text { S } \\ \text { R } & \text { S }\end{array}$

Symbols used for susceptibility of bacteria to antibiotics: S - susceptible, MS - medium susceptible, R - resistant

* species that are typically saprophytic in the environment

Table 6.

Results of antibiograms for individual bacteria from the Enterobacteriaceae family and saprophytic bacteria isolated from soil after a year from fertilization with sewage sludge

\begin{tabular}{|c|c|c|c|c|c|c|c|c|c|}
\hline \multirow{2}{*}{$\begin{array}{l}\text { Bacteria } \\
\text { species } \\
\text { isolated } \\
\text { from soil }\end{array}$} & \multirow{2}{*}{$\begin{array}{l}\text { Dose of } \\
\text { sewage } \\
\text { sludge } \\
\text { applied } \\
\text { for soil } \\
\text { fertilization } \\
\text { [t/ha] }\end{array}$} & \multicolumn{8}{|c|}{ Type of antibiotic used } \\
\hline & & 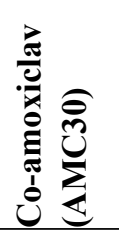 & 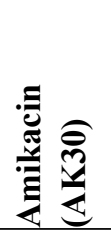 & 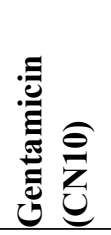 & 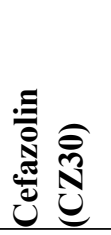 & 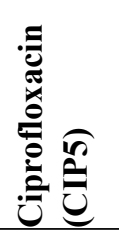 & 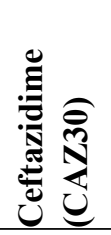 & 量昰 & 这 \\
\hline Citrobacter freundii & $20,30,40$ & $\mathrm{~S}$ & $\mathrm{~S}$ & $\mathrm{~S}$ & $\mathrm{~S}$ & $\mathrm{~S}$ & $\mathrm{~S}$ & $\mathrm{R}$ & $\mathrm{S}$ \\
\hline $\begin{array}{l}\text { Morganella } \\
\text { morganii }\end{array}$ & $10,20,30,40$ & $\mathrm{R}$ & $\mathrm{S}$ & $\mathrm{S}$ & $\mathrm{R}$ & $\mathrm{S}$ & $\mathrm{S}$ & $\mathrm{R}$ & MS \\
\hline $\begin{array}{l}\text { Klebsiella } \\
\text { pneumoniae }\end{array}$ & $10,20,30,40$ & S & $\mathrm{S}$ & $\mathrm{S}$ & S & S & S & MS & $\mathrm{S}$ \\
\hline Klebsiella oxytoca & 30,40 & $\mathrm{~S}$ & MS & S & $\mathrm{S}$ & $\mathrm{S}$ & $\mathrm{S}$ & $\mathrm{R}$ & $\mathrm{S}$ \\
\hline $\begin{array}{l}\text { Yersinia } \\
\text { enterocolitica }\end{array}$ & $10,20,30,40$ & $\mathrm{R}$ & $\mathrm{S}$ & $\mathrm{R}$ & $\mathrm{S}$ & $\mathrm{S}$ & $\mathrm{R}$ & $\mathrm{R}$ & $\mathrm{S}$ \\
\hline $\begin{array}{l}\text { Serratia } \\
\text { marcescens }\end{array}$ & $10,20,30,40$ & $\mathrm{~S}$ & $\mathrm{~S}$ & S & $\mathrm{R}$ & $\mathrm{S}$ & $\mathrm{S}$ & MS & S \\
\hline Serratia rubidaea & $20,30,40$ & $\mathrm{~S}$ & $\mathrm{~S}$ & $\mathrm{~S}$ & MS & $\mathrm{S}$ & $\mathrm{S}$ & MS & $\mathrm{S}$ \\
\hline $\begin{array}{l}\text { Burkholderia } \\
\text { pseudomallei }\end{array}$ & $20,30,40$ & $\mathrm{R}$ & $\mathrm{S}$ & S & $\mathrm{S}$ & $\mathrm{S}$ & S & $\mathrm{R}$ & S \\
\hline $\begin{array}{l}\text { Pseudomonas } \\
\text { fluorescens* }\end{array}$ & $10,20,30,40$ & MS & $\mathrm{S}$ & S & $\mathrm{S}$ & $\mathrm{S}$ & $\mathrm{S}$ & $\mathrm{S}$ & $\mathrm{S}$ \\
\hline $\begin{array}{l}\text { Alcaligenes } \\
\text { faecalis* }\end{array}$ & $20,30,40$ & $\mathrm{~S}$ & $\mathrm{~S}$ & $\mathrm{R}$ & $\mathrm{S}$ & $\mathrm{S}$ & $\mathrm{S}$ & $\mathrm{R}$ & $\mathrm{R}$ \\
\hline Eschericha coli & $10,20,30,40$ & $\mathrm{~S}$ & $\mathrm{~S}$ & $\mathrm{~S}$ & $\mathrm{~S}$ & $\mathrm{~S}$ & $\mathrm{~S}$ & $\mathrm{~S}$ & $\mathrm{~S}$ \\
\hline Eschericha coli & 30,40 & MS & $\mathrm{S}$ & $\mathrm{S}$ & $\mathrm{S}$ & $\mathrm{S}$ & $\mathrm{S}$ & $\mathrm{R}$ & $\mathrm{S}$ \\
\hline E. coli-inactive $L^{+}$ & $10,20,30,40$ & $\mathrm{R}$ & $\mathrm{S}$ & $\mathrm{S}$ & S & S & S & $\mathrm{R}$ & S \\
\hline E. coli-inactive $L-$ & $10,20,30,40$ & $\mathrm{~S}$ & $\mathrm{~S}$ & $\mathrm{~S}$ & $\mathrm{~S}$ & $\mathrm{~S}$ & $\mathrm{~S}$ & $\mathrm{R}$ & $\mathrm{S}$ \\
\hline Enteric Group & $20,30,40$ & MS & $\mathrm{S}$ & $\mathrm{S}$ & $\mathrm{S}$ & $\mathrm{S}$ & $\mathrm{S}$ & $\mathrm{R}$ & S \\
\hline
\end{tabular}


Table 7.

Results of antibiograms for individual bacteria from the Enterobacteriaceae family and saprophytic bacteria isolated in water leachates from soil fertilized with sewage sludge

\begin{tabular}{|c|c|c|c|c|c|c|c|c|c|}
\hline \multirow{2}{*}{$\begin{array}{l}\text { Bacteria species } \\
\text { isolated } \\
\text { from water }\end{array}$} & \multirow{2}{*}{$\begin{array}{l}\text { Dose of sewage } \\
\text { sludge applied } \\
\text { for soil } \\
\text { fertilization } \\
\text { [t/ha] }\end{array}$} & \multicolumn{8}{|c|}{ Type of antibiotic used } \\
\hline & & 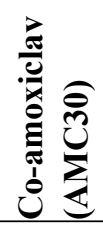 & 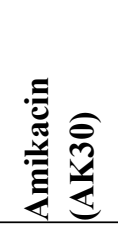 & 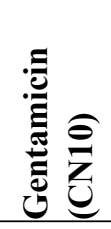 & 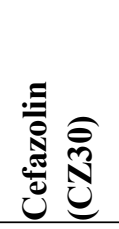 & 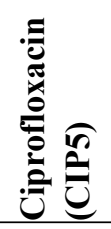 & 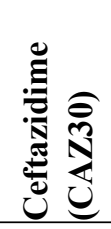 & 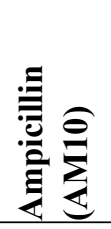 & 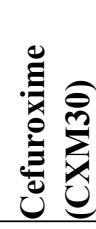 \\
\hline $\begin{array}{l}\text { Morganella } \\
\text { morganii }\end{array}$ & $20,30,40$ & $\mathrm{R}$ & $\mathrm{R}$ & $\mathrm{S}$ & $\mathrm{R}$ & $\mathrm{S}$ & $\mathrm{S}$ & $\mathrm{R}$ & MS \\
\hline $\begin{array}{l}\text { Klebsiella } \\
\text { pneumoniae }\end{array}$ & $20,30,40$ & $\mathrm{~S}$ & $\mathrm{~S}$ & $\mathrm{~S}$ & $\mathrm{~S}$ & $\mathrm{~S}$ & $\mathrm{~S}$ & MS & $\mathrm{S}$ \\
\hline Klebsiella oxytoca & $20,30,40$ & $\mathrm{~S}$ & $\mathrm{~S}$ & $\mathrm{~S}$ & $\mathrm{~S}$ & $\mathrm{~S}$ & $\mathrm{~S}$ & $\mathrm{R}$ & $\mathrm{S}$ \\
\hline Yersinia aldovae & 30,40 & $\mathrm{~S}$ & $\mathrm{~S}$ & S & $\mathrm{S}$ & $\mathrm{S}$ & $\mathrm{S}$ & $\mathrm{R}$ & $\mathrm{S}$ \\
\hline $\begin{array}{l}\text { Yersinia } \\
\text { enterocolitica }\end{array}$ & $20,30,40$ & $\mathrm{R}$ & $\mathrm{S}$ & $\mathrm{R}$ & $\mathrm{S}$ & $\mathrm{S}$ & $\mathrm{R}$ & $\mathrm{R}$ & $\mathrm{S}$ \\
\hline Serratia marcescens & $20,30,40$ & $\mathrm{~S}$ & $\mathrm{~S}$ & $\mathrm{~S}$ & $\mathrm{R}$ & $\mathrm{S}$ & $\mathrm{S}$ & $\mathrm{S}$ & $\mathrm{S}$ \\
\hline Serratia rubidaea & 30.40 & $\mathrm{~S}$ & $\mathrm{~S}$ & $\mathrm{~S}$ & $\mathrm{~S}$ & $\mathrm{~S}$ & $\mathrm{~S}$ & MS & S \\
\hline $\begin{array}{l}\text { Pseudomonas } \\
\text { fluorescens* }\end{array}$ & $10,20,30,40$ & $\mathrm{R}$ & $\mathrm{S}$ & $\mathrm{S}$ & $\mathrm{S}$ & $\mathrm{S}$ & $\mathrm{S}$ & $\mathrm{S}$ & $\mathrm{S}$ \\
\hline $\begin{array}{l}\text { Alcaligenes } \\
\text { faecalis* }\end{array}$ & $20,30,40$ & $\mathrm{~S}$ & $\mathrm{~S}$ & $\mathrm{R}$ & $\mathrm{S}$ & $\mathrm{S}$ & $\mathrm{S}$ & $\mathrm{R}$ & MS \\
\hline Providencia rettgeri & 30,40 & $\mathrm{~S}$ & $\mathrm{~S}$ & $\mathrm{~S}$ & $\mathrm{~S}$ & $\mathrm{~S}$ & $\mathrm{~S}$ & MS & $\mathrm{S}$ \\
\hline Eschericha coli & $10,20,30,40$ & $\mathrm{~S}$ & $\mathrm{~S}$ & $\mathrm{~S}$ & $\mathrm{~S}$ & $\mathrm{~S}$ & $\mathrm{~S}$ & $\mathrm{~S}$ & $\mathrm{~S}$ \\
\hline Eschericha coli & $20,30,40$ & MS & $\mathrm{S}$ & $\mathrm{S}$ & $\mathrm{S}$ & $\mathrm{S}$ & $\mathrm{S}$ & $\mathrm{R}$ & $\mathrm{S}$ \\
\hline E. coli-inactive $L^{+}$ & $20,30,40$ & $\mathrm{R}$ & $\mathrm{S}$ & $\mathrm{S}$ & $\mathrm{S}$ & $\mathrm{S}$ & $\mathrm{S}$ & $\mathrm{R}$ & S \\
\hline E. coli-inactive $L-$ & $20,30,40$ & $\mathrm{~S}$ & $\mathrm{~S}$ & $\mathrm{~S}$ & $\mathrm{~S}$ & $\mathrm{~S}$ & $\mathrm{~S}$ & MS & $\mathrm{S}$ \\
\hline Enteric Group & $10,20,30,40$ & $\mathrm{R}$ & $\mathrm{S}$ & $\mathrm{S}$ & $\mathrm{S}$ & $\mathrm{S}$ & $\mathrm{S}$ & $\mathrm{R}$ & S \\
\hline
\end{tabular}

Symbols used for susceptibility of bacteria to antibiotics: S - susceptible, MS - medium susceptible, R - resistant

$260 *$ species that are typically saprophytic in the environment 


\section{Table 8.}

278

Results of antibiograms for bacteria from the Enterococcus genus isolated from the sewage sludge, soil fertilized with sewage sludge and water leachates

\begin{tabular}{|c|c|c|c|c|c|c|c|c|c|c|c|}
\hline \multicolumn{2}{|c|}{$\begin{array}{l}\text { Species } \\
\text { of isolated bacteria }\end{array}$} & 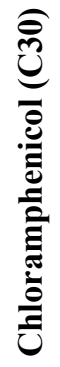 & 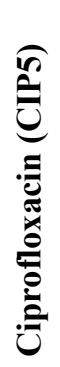 & 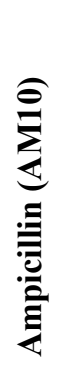 & 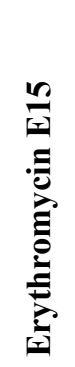 & 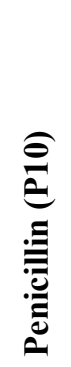 & 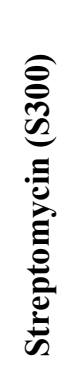 & 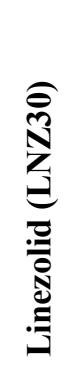 & 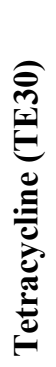 & 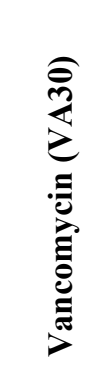 & 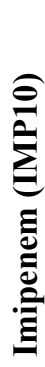 \\
\hline \multirow{3}{*}{ 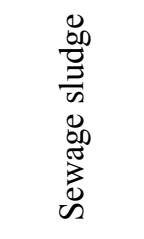 } & E. faecalis & $\mathrm{S}$ & $\mathrm{S}$ & $\mathrm{S}$ & $\mathrm{R}$ & MS & $\mathrm{R}$ & $\mathrm{R}$ & $\mathrm{S}$ & $\mathrm{S}$ & $\mathrm{S}$ \\
\hline & E. faecium & S & $\mathrm{S}$ & $\mathrm{S}$ & MS & MS & $\mathrm{S}$ & S & S & S & $\mathrm{S}$ \\
\hline & E. gallinarum & S & S & $\mathrm{S}$ & MS & MS & S & S & S & MS & $\mathrm{S}$ \\
\hline \multirow{3}{*}{ 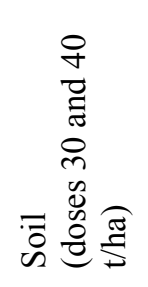 } & E. faecalis & $\mathrm{S}$ & $\mathrm{S}$ & $\mathrm{S}$ & $\mathrm{R}$ & MS & $\mathrm{R}$ & MS & S & $\mathrm{S}$ & S \\
\hline & E. faecium & S & S & $\mathrm{S}$ & MS & MS & S & S & S & S & $\mathrm{S}$ \\
\hline & E. gallinarum & $\mathrm{S}$ & S & S & MS & MS & S & S & S & $\mathrm{S}$ & $\mathrm{S}$ \\
\hline 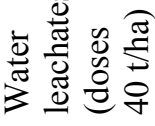 & E. faecalis & $\mathrm{S}$ & $\mathrm{S}$ & S & $\mathrm{R}$ & MS & MS & MS & S & $\mathrm{S}$ & $\mathrm{S}$ \\
\hline
\end{tabular}

\section{Discussion} diseases in humans and animals in contact with sewage sludge used in the experiment,

287 fertilized soils and soil leachates. The sanitary condition of the sewage sludge depends on

288 the type of technological processes used to treat wastewater. The most frequent processes 289 used to limit the amount of pathogens include methane fermentation of both wastewater 
and sewage sludge $[29,30]$. Further hygienization of this waste can be achieved by e.g.

291 liming or composting [31]..

292 In the case of the bacteria from Enterobacteriaceae and Enterococcus families determined

293 in the examinations of sanitary indices, their presence was demonstrated in the analysed 294 samples of sewage sludge, fertilized soil and water leachates. Intestinal bacteria count 295 (Enterobacteriaceae) was at a worrying high level. Presence of enterococci was also found 296 (Tab. 8). However, only very small contents were observed for these bacteria, especially in 297 the soil fertilized by sewage sludge.

298 Furthermore, no excessive migration to groundwater was found with increasing the dose of 299 the sludge (Tab. 3 and 4). Therefore, they do not represent a major epidemiological 300 problem in the examined environments according to the recommended standards. Only $E$.

301 faecalis migrated to soil leachates fertilized with sewage sludge from three bacterial species 302 of the Enterococcus family determined in sewage sludge. Despite a low count of bacteria 303 from this species, their resistance to erythromycin and mean resistance to penicillin, 304 streptomycin and linezoid were determined. Similar results were obtained by Da Silva et al. 305 [32]. In the raw wastewater, these researchers found Entercoccus hirae, Entercoccus 306 faecium and Entercoccus faecalis. A decrease in the count of Entercoccus hirae bacteria 307 and an increase in the count of Entercoccus faecium and Entercoccus faecalis were found 308 in the treated municipal wastewater. Both species were characterized by $40 \%$ resistance to 309 erythromycin. Drug-resistant strains of enterococci were not eliminated through wastewater 310 treatment. Da Costa et al. also isolated Enterococcus bacteria in sewage and sewage sludge 311 which showed $24.8 \%$ resistance to erythromycin. In $49.4 \%$, they also showed multi-drug 312 resistance [33]. These are bacteria that represent a serious epidemiological threat $[34,35]$.

313 In this study, the doses of sewage sludge of $10,20,30$ and 40 t/ha did not cause 314 contamination by these microorganisms. However, there is a risk that microbiological 
315 contamination with drug-resistant forms may already be significant after the application of

316 higher doses.

317 The group of intestinal bacteria from the Enterobacteriaceae family dominated in the 318 sewage sludge used for fertilization (Tab. 2). Among them, many isolated species (Tab. 5) 319 have shown resistance to the antibiotics used. These are the drugs that are most often used 320 to combat these forms of microorganisms. Ampicilin turned out to be the least effective 321 drug for the determined bacteria. Among the isolated species, $68.2 \%$ showed resistance to 322 this drug, while $13.6 \%$ showed average resistance. Only $13.6 \%$ of the intestinal bacteria 323 tested in the sewage sludge were sensitive to this antibiotic. Similarly high ampicilin 324 resistance in Enterobacteriaceae was observed in a study by Mahmud et al. [36].

In research $36.6 \%$ of the isolated bacteria were resistant to co-amoxiclav.

326 Ciprofloxacin $(100 \%$ sensitivity) proved to be the most effective antibiotic against the 327 determined microorganisms.

328 Some pathogenic organisms that were isolated from sewage sludge should also be 329 emphasized. Particularly dangerous are Klebsiella oxytoca species, considered to be alert 330 bacteria. They can cause haematosepsis and various infections. Its resistance to the 331 amikacin and ampicillin used in the experiments may be dangerous. These organisms may 332 migrate to soils fertilized with sewage sludge and further to groundwater, which was 333 confirmed in the study. This phenomenon was particularly observed after the application of 334 doses of sewage sludge of 30 and $40 \mathrm{t} / \mathrm{ha}$. A similar phenomenon was observed in the case 335 of the equally dangerous Klebsiella pneumoniae bacteria. Both species very quickly and 336 easily become resistant to most antibiotics. Other experiments performed by the authors 337 [18] also indicated the likelihood of presence and migration of these bacteria from the 338 sewage sludge to soil, especially if higher doses of sewage sludge are applied. An increase 339 in the degree of resistance of isolated bacteria was also observed at that time. 
Among the isolated bacteria from the Enterobacteriaceae family, the species

341 Escherichia coli occurred in large counts. The studies found different groups of these

342 microorganisms that differed in reaction to the antibiotics used. Some were entirely

343 sensitive to all drugs. Others, however, showed resistance mainly to co-amoxiclav and

344 ampicillin. Differences in the reaction were also observed in relation to the presence of

345 unstable forms of $\mathrm{L}+$ and L- among isolated E. coli bacteria. Some authors [37] have

346 demonstrated that L-forms (with cells of this shape), also called wild strains, are resistant to

347 penicillin. The studies also showed resistance to ampicillin.

348 Some E. coli bacteria can contaminate plant biomass through soil and water.

349 Multi-drug-resistant strains are particularly dangerous [38]. Other authors found the

350 presence of other drug-resistant Acinetobacter bacteria in the biomass of lettuce and fruit

$351 \quad[39]$.

352 Other dangerous bacteria isolated from the sewage sludge that migrated to soil and

353 groundwater were Serratia marcescens and Serratia rubidaea. S. marcescens bacteria were

354 initially considered non-hazardous saprophytic microorganisms, occurring mainly in

355 aquatic environments. The first documented cases of human infection were found in the

356 area of Great Britain at the beginning of the 20th century. Since then, further reports of

357 urinary tract and endocardial infections, meningitis and sepsis have also been documented.

358 Some researchers demonstrated a substantial intensification of the problem of

359 hospital-acquired conditions caused by S. marcescnes in neonatal and paediatric wards.

360 Depending on the centre studied, S. marcescens bacteria account for between 5 and $16 \%$ of

361 nosocomial infections among newborns and infants [40]. The species $S$. marcescens are

362 microorganisms resistant to numerous groups of antibiotics. Resistance to cefazolin was

363 found in the present study. The migration of these bacteria to soils fertilized with sludge

364 and groundwater seems to be worrying. 
Yersinia bacteria were detected in sewage sludge, fertilized soils and infiltrating water.

366 Isolated species of $Y$. enterocolitica and $Y$. aldovae can cause many diseases. $Y$.

367 enterocolitica bacteria cause yersiniosis, systemic infections and haematosepsis, which are

368 dangerous for human health. Isolated in the study, these bacteria turned out to be resistant

369 to many antibiotics including: co-amoxiclav, gentamicin, ceftazidime and ampicillin. 


\section{Conclusions}

1. The results of the study showed that the fertilization with sewage sludge at all doses affected the sanitary condition of the fertilized sandy soil. Only non-fertilised control soil could be classified as sanitary clean. The lowest level of contamination was found after application of the dose of sewage sludge of $10 \mathrm{t} / \mathrm{ha}$.

2. The research indicates a significant problem of the risk of occurrence of various diseases in humans and animals in contact with sewage sludge and with soil and soil leachates fertilized with this sludge. Many drug-resistant bacteria were isolated from the material studied, including Klebsiella oxytoca, which is considered to be an "alert bacterium".

3. The results show that pathogenic microorganisms, including those drug-resistant, can migrate from sewage sludge to soil and further to groundwater.

4. Most often isolated drug-resistant strains of intestinal bacteria were less sensitive to older types of antibiotics, including cefazolin, ampicillin and co-amoxiclav.

5. Resistance of several isolated strains of intestinal bacteria to newer antibiotics, e.g. ceftazidime is worrying. However, the determined bacteria were not resistant to ciprofloxacin.

Acknowledgments: The scientific research was funded by the statute subvention of Czestochowa University of Technology, Faculty of Infrastructure and Environment

Author Contributions: E. Stańczyk-Mazanek conceived and designed the experiments and performed the experiments; E. Stańczyk-Mazanek, L. Stępniak analyzed the data and wrote the paper. 


\section{References}

403

1. Casanova L.M., Sobsey M.D., 2016. Antibiotic-resistant enteric bacteria in environmental waters. Water 8,561 .

2. Robredo B., Singh K. V., Baquero F., Murray

B. E., Torres C., 2000. of Food Microbiology 54, 197-204.

3. Chajecka-Wierzchowska W., Zadernowska A., Łaniewska-Trokenheim Ł., 2017.

Virulence factors of Enterococcus spp. presented in food. LWT - Food Science and Technology 75, 670-676.

4. Al-Bahry S.N., Mahmoud I.Y., Al-Belushi K.I.A., Elshafie A.E., Al-Harthy A., antibiotic resistant enteric bacteria and enteric pathogens as bio-indicators of pollution.

5. Ory J., Bricheux G., Togola A., Bonnet J.L., Donnadieu-Bernard F., Nakusi L., Forestier Ch., Traore O., 2016. Ciprofloxacin residue and antibiotic-resistant biofilm bacteria in hospital effluent. Environ Pollut. 214, 635-645.

6. Rabbani M. A. G., Howlader Md. Z. H., Kabir Y., 2017. Detection of multidrug resistant Chemosphere 77, 1534-1539.

7. Anderson, M., Sobsey, M., 2006. Detection and occurrence of antimicrobially resistant E. coli in groundwater on or near swine farms in eastern north carolina. Water Sci. Technol. 54, 211-218.

8. Heaney, C.D., Myers, K., Wing, S., Hall, D., Baron, D., Stewart, J.R., 2015. Source tracking swine fecal waste in surface water proximal to swine concentrated animal feeding operations. Sci. Total Environ. 511, 676-683. 
9. Ji-Ran Y., Soon-Uk Y., Chang-Gyun K., 2017. Quantification of residual antibiotics in cow manure being spread over agricultural land and assessment of their behavioral effects on antibiotic resistant bacteria. Chemosphere 182, 771-780.

10. Osińska A., Korzeniewska E., Harnisz M., Niestępski S., 2017. The prevalence and characterization of antibiotic-resistant and virulent Escherichia coli strains in the municipal wastewater system and their environmental fate. Science of the Total Environment, 577, 367-375.

11. Yeom J. R., Yoon S. U., Kim Ch. G., 2017. Quantification of residual antibiotics in cow manure being spread over agricultural land and assessment of their behavioral effects on antibiotic resistant bacteria. Chemosphere 182, 771-780.

12. Bondarczuk K., Markowicz A., Piotrowska-Seget Z., 2016. The urgent need for risk assessment on the antibiotic resistance spread via sewage sludge land application. Environment International 87, 49-55.

13. Harnisz M., Korzeniewska E., 2018. The prevalence of multidrug-resistant Aeromonas spp. in the municipal wastewater system and their dissemination in the environment. Sci. Total Environ. 626, 377-383.

14. Marinho C., Silva N., Pombo S., Santos T., Monteiro R., Gonçalves A., Micael J., Rodrigues P., Costa A. C., Igrejas G., Poeta P., 2013. Echinoderms from Azores islands: An unexpected source of antibiotic resistant Enterococcus spp. and Escherichia coli isolates. Marine Pollution Bulletin 69, 122-127.

15. Dib A.L., Agabou A., Chahed A., Kurekci C., Moreno E., Espigares M., Espigares E., 2018. Isolation, molecular characterization and antimicrobial resistance of enterobacteriaceae isolated from fish and seafood. Food Control 88, 54-60.

16. Lamba M., Ahammad S. Z., 2017. Sewage treatment effluents in Delhi: A key contributor of b-lactam resistant bacteria and genes to the environment. Chemosphere 2017, 188, $249-256$. 
454

17. Singh R.P., Agrawal M., 2008. Potential benefits and risks of land application of sewage sludge. Waste Management 28, 347-358.

18. Stańczyk-Mazanek E., Nalewajek T., Zabochnicka M., 2012. Drug-resistant microorganisms in soils fertilized with sewage sludge. Archives Environmental Protection 38, no 1, 97-102.

19. Reinthaler F.F., Posch J., Feierl G., Wust G., Haas D., Ruckenbauer G., Mascher F., Marth E., 2003. Antibiotic resistance of E. coli in sewage and sludge. Water Research 2003, 37, 1685-1690.

20. Markiewicz Z., Kwiatkowski Z. A., 2017. Bacteria, antibiotics, drug resistance, Polish Scientific Publishers PWN, (in Polish).

21. Ostrowska A., Gawliński S., Szczubiałka Z., 1991. Methods of analysis and assessment of soil and plant properties. Catalog. Institute of Environmental Protectio (in Polish).

22. Regulation of the Minister of the Environment of February 6, 2015 on municipal sewage sludge (in Polish).

23. Kańska Z., Grabińska-Łoniewska A., Łebkowska M., Rzechowska E., 2006. Laboratory exercises in sanitary biology. Warsaw University of Technology Publishing House,

24. Hryniewicz W., Sulikowska A., Szczypa K., Krzystoń-Russjan J., Gniadkowski M., 2001. Recommendations for the selection of tests for the determination of bacterial susceptibility to antibiotics and chemotherapeutics. National Reference Center for Microbial Susceptibility (in Polish).

25. Hryniewicz W., Żabicka D., 2016. Position of the Working Group on the determination of susceptibility in accordance with the EUCAST recommendations on the most frequently asked questions regarding the use of recommendations EUCAST (in Polish). 
26. Interpretation tables for minimum inhibitory concentrations (MICs) and size of growth inhibition zones, 2015. The European Committee on Antimicrobial Susceptibility Testing - (EUCAST), Version 5.0.

27. Regulation of the Minister of the Environment of September 1, 2016 on the way of assessing the pollution of the earth's surface (in Polish).

28. Regulation of the Minister of Health of December 7, 2017 on the quality of water intended for human consumption (in Polish).

29. Wolski P., Zawieja I., 2014. Hybrid conditioning before anaerobic digestion for the improvement of sewage sludge dewatering. Desal. and Wat. Treat. 52, 3725-3731.

30. Tong J., Liu J., Zheng X., Zhang J., Ni X., Chen M., Wei Y., 2016. Fate of antibiotic resistance bacteria and genes during enhanced anaerobic digestion of sewage sludge by microwave pretreatment. Bioresource. Technology 217, 37-43.

31. Singh R., Jiang X., Luo F., 2010. Thermal inactivation of heat-shocked Escherichia coli o157:h7, Salmonella, and Listeria monocytogenes in dairy compost. Journal of Food Protection 73, No. 9, 1633-1640.

32. Da Silva M. F., Veríssimo I. T. A., Boaventura R. A. R., Célia O. C. N., Manaia M., 2006. Antibiotic resistance of enterococci and related bacteria in an urban wastewater treatment plant. FEMS Microbiology Ecology 55, 2, 322-329.

33. Da Costa P.M., Vaz-Pires P., Bernardoc F., 2006. Antimicrobial resistance in Enterococcus spp. isolated in inflow, effluent and sludge from municipal sewage water treatment plants. Water Res. 40, $1735-1740$.

34. Oravcova V., Mihalcin M., Zakova J., Pospisilova L., Masarikova M., Literaka I., 2017. Vancomycin-resistant enterococci with vanA gene in treated municipal wastewater and their association with human hospital strains. Science of the Total Environment 609, $633-643$. 
35. Monticelli J., Knezevich A., Luzzati R., Di Bella S., 2018. Clinical management of non-faecium non-faecalis vancomycin-resistant enterococci infection. Focus on Enterococcus gallinarum and Enterococcus casseliflavus/flavescens. J. Infect Chemother 24, 237-246.

36. Mahmoud I. Y., Al-Bahry S. N., Al-Musharafi S. K., 2013. Fresh water habitat pollution by treated sewage effluent in relation to multiple-antibiotic-resistant bacteria. APCBEE Procedia 5, $363-367$.

37. Joseleau-Petit D., Liébart J. C., Ayala J. A., D'Ari R., 2007. Unstable Escherichia coli L forms revisited: growth requires peptidoglycan synthesis. J Bacteriol 189 (18),

38. Gomez-Aldapa C.A., Segovia-Cruz J.A., Cerna-Cortes J.F., Rangel-Vargas E., Salas-Rangel L.P., Eduardo J., Gutierrez-Alcantara E.J., Castro-Rosas J., 2016. Prevalence and behavior of multidrug-resistant shiga toxin-producing Escherichia coli, enteropathogenic E. coli and enterotoxigenic E. coli on Coriander. Food Microbiology

39. Carvalheira A., Silva J., Teixeira P., 2017. Lettuce and fruits as a source of multidrug resistant Acinetobacter spp. Food Microbiology 64, 119-125.

40. Celejewski-Marciniak P., Tyski S., 2011. Sticks of the genus Serratia: characteristics of species, pathogenicity and resistance to antibiotics Serratia marcescens. POST. MIKROBIOL. 50, 4, 291-302. 